\title{
Bioactivity Evaluation of Plant Extracts Used in Indigenous Medicine against the Snail, Biomphalaria glabrata, and the Larvae of Aedes aegypti
}

\author{
Edilson Alves dos Santos, ${ }^{1,2,3}$ Cenira M. de Carvalho, ${ }^{1}$ Ana L. S. Costa, ${ }^{1}$ \\ Adilva S. Conceição, ${ }^{2}$ Flávia de B. Prado Moura, ${ }^{4}$ and Antônio Euzébio Goulart Santana ${ }^{1}$ \\ ${ }^{1}$ Laboratório de Produtos Naturais, Instituto de Química e Biotecnologia, Universidade Federal de Alagoas, 57072-970 Maceió, \\ AL, Brazil \\ ${ }^{2}$ Universidade do Estado da Bahia, Herbário da Universidade do Estado da Bahia, HUNEB-Coleção, 48608-230 Paulo Afonso, \\ BA, Brazil \\ ${ }^{3}$ Departamento de Educação, Universidade do Estado da Bahia, Campus VIII, Rua do Bom Conselho 179, 48600-000 Paulo Afonso, \\ BA, Brazil \\ ${ }^{4}$ Instituto de Ciências Biológicas e da Saúde, MHN, Universidade Federal de Alagoas, 57072-970 Maceió, AL, Brazil
}

Correspondence should be addressed to Antônio Euzébio Goulart Santana, aegs@qui.ufal.br

Received 12 July 2011; Revised 2 September 2011; Accepted 15 September 2011

Academic Editor: Ulysses Paulino De Albuquerque

Copyright (C) 2012 Edilson Alves dos Santos et al. This is an open access article distributed under the Creative Commons Attribution License, which permits unrestricted use, distribution, and reproduction in any medium, provided the original work is properly cited.

\begin{abstract}
This investigation examined the molluscicidal and larvicidal activity of eight plants that are used in the traditional medicine of the Pankararé indigenous people in the Raso da Catarina region, Bahia state, Brazil. The tested plants were chosen based on the results of previous studies. Only those plants that were used either as insect repellents or to treat intestinal parasitic infections were included in the study. Crude extracts (CEs) of these plants were tested for their larvicidal activity (against Aedes aegypti larvae in the fourth instar) and molluscicidal activity (against the snail Biomphalaria glabrata). The plant species Scoparia dulcis and Helicteres velutina exhibited the best larvicidal activities ( $\mathrm{LC}_{50} 83.426 \mathrm{mg} / \mathrm{L}$ and $\mathrm{LC}_{50} 138.896 \mathrm{mg} / \mathrm{L}$, resp.), and Poincianella pyramidalis, Chenopodium ambrosoides, and Mimosa tenuiflora presented the best molluscicidal activities ( $\mathrm{LC}_{50} 0.94 \mathrm{mg} / \mathrm{L}, \mathrm{LC}_{50} 13.51 \mathrm{mg} / \mathrm{L}$, and $\mathrm{LC}_{50} 20.22 \mathrm{mg} / \mathrm{L}$, resp.). As we used crude extracts as the tested materials, further study is warranted to isolate and purify the most active compounds.
\end{abstract}

\section{Introduction}

The Brazilian northeast is the poorest region of Brazil and has the worst Human Development Indices [1]. Most of this population is subjected to neglected tropical diseases that predominantly affect the poorest and most vulnerable groups, contributing to the perpetuation of poverty, inequality, and social exclusion [2].

Schistosomiasis and dengue fever cause major public health concerns in Brazil and other tropical developing countries. Schistosomiasis is caused by the parasite, Schistosoma mansoni, which uses the Biomphalaria glabrata snail as an essential intermediate host in its life cycle. Dengue fever is caused by an arbovirus of the Flaviviridae family and is transmitted by the mosquito, Aedes aegypti.

The number of cases of dengue has grown in Brazil, with epidemics in the most densely populated urban areas. However, natural products with different biocidal activities can help to fight parasite vectors at the adult or larval stages and can act as alternatives to synthetic products due to their rapid biodegradation and lower cost [3].

Molluscicides have been used as a general strategy to eliminate the snail that transmits schistosomiasis [4]. According to the World Health Organization (WHO), the use of drug therapy in conjunction with the use of molluscicides is the use the most valuable method to control schistosomiasis 
in areas with intermediary hosts. The synthetic substance, niclosamide (Bayluscide), has been used as the standard molluscicide since the 1960s, as it is efficient in controlling snails; however, the high cost of niclosamide and the fact that it decomposes rapidly in the presence of sunlight have limited the use of this drug [5].

Popular knowledge has been an important source of information for scientific research in several areas of study. Ethnopharmacological and ethnobotanical investigations have been used as the main strategy for selecting medicinal plants, thereby shortening the time for the discovery of new drugs, whereas ethnodirected research consists of selecting species based on information from population groups [6].

Evidence for the efficacy and safety and the immediate availability of plant-derived products for the control or eradication of such diseases would be of great value because part of the population living in the affected areas use plants and animals as one of the few options for disease treatment [7-9].

Studies have found evidence that standard methods control the dengue-related mosquito larvae with low efficacy, a situation that demonstrates the need for other means to fight the proliferation of dengue [10] given the fact that results in epidemiology are context-dependent [11]. Similarly, despite the fact that a national schistosomiasis control program was implemented in 1975, the disease still occurs in 19 states and is endemic to eight states.

Ethnobiological studies have been carried out on the indigenous Pankararé people since 1993 [12]. In 2006 [13], the use of 64 plants was reported, 20 of which were used for medicinal purposes. Indeed, there is evidence that the Pankararé-in the Estação Ecologica Raso da Catarina (a conservation area), Bahia state-have a profound knowledge regarding the benefits of plants.

This study examines the molluscicidal and larvicidal effects of eight plants used by the Pankararé indigenous people for medicinal purposes. The aim of the study is to look for evidence of alternative methods to fight vectors of schistosomiasis and dengue, taking into account local potentialities.

\section{Materials and Methods}

2.1. Study Area and Population. The indigenous lands of the Pankararé are located in one of the driest of the Brazilian regions, with an average annual rainfall of between 450 and $600 \mathrm{~mm}$ [14] and an average annual temperature of $25^{\circ} \mathrm{C}$; the climate is arid and semiarid. The natural vegetation is tropical dry forest of the type hyperxerophylous steppic savanna.

The Pankararé have a long history of interaction with their regional neighbors and are a peasant social group that sees itself as a distinct ethnic group among the regional populations (from the social organization standpoint, this is termed Indigenous Peasantry). In Brazilian indigenous communities, the central political figure is the Cacique [15]. The Pankararé comprise a very poor group that has a long history of territorial disputes. They practice subsistence agriculture, farm livestock on a small scale, and engage in other activities, such as hunting, the collection of honey and wild fruits, and handicrafts [16].

2.2. Ethnobotanical Survey and Plant Collection. Ethnobiologic studies have been carried out on the Pankararé indigenous people since 1993. However, the present study was based mainly on recent information [17], specifically, on studies that were conducted in 2008 and 2009. The ethnobotanical research was carried out after the community members were fully informed of its purpose and they had granted their permission to record information. Authorization was also obtained from the community Cacique and the National Foundation of Support to the Indians (FUNAI). The data were collected using some of the methods presented and discussed in a previous report [18], including the use of informal conversations and semistructured interviews with 35 residents of the indigenous community ( 9 men and 26 women, aged 23 to 64 years). The interviewees were identified using the snowball technique based on the information initially provided by the traditional specialists, that is, people that are knowledgeable about medicinal plants.

For the taxonomic identification of the species, we collected reproductive plants that were donated to and identified in the Herbarium of the University of Bahia State UNEB (HUNEB-Coleção, Paulo Afonso).

2.3. Obtaining the Extracts. Eight plants were tested in bioassays to evaluate their larvicidal and molluscicidal activities. Plants that are used as insect repellents or anthelmintics were included in the study. To obtain the extracts, botanical material was gathered between March 2008 and February 2009. Material of the collected species (roots, stems, stem bark, and leaves) was dried at room temperature and then ground to powder. From this powder, we obtained the crude extract (CE) of each material by extracting three consecutive times with $90 \%$ ethanol for $72 \mathrm{~h}$ in a stainless steel extractor at $27 \pm 1^{\circ} \mathrm{C}$ followed by the remotion of the solvent in a rotary evaporator at $60^{\circ} \mathrm{C}$. The concentrated and weighed crude extracts were bioassayed to evaluate their larvicidal and molluscicidal activities at the Institute of Chemistry and Biotechnology (IQB) at the Federal University of Alagoas, UFAL.

2.4. Evaluation of the Molluscicidal Activity. Individual snails of the species Biomphalaria glabrata (of diameter 13-18 mm and obtained from the Institute René Rachou in Belo Horizonte city) were housed in aquaria equipped with continuously circulating dechlorinated water, at the temperature of $28^{\circ} \mathrm{C}$, in the bioassay laboratory of the IQB of UFAL, based on the protocol of Santos and Sant'ana [19]. The ethanolic extracts of the stems, stem bark, roots, and leaves of the plants were dissolved in an aqueous solution of Dimethyl Sulfoxide (DMSO $0.1 \%$ ) to obtain various concentrations $(0.10-100 \mu \mathrm{g} / \mathrm{mL})$. The assay consisted of immersing five snails in $125 \mathrm{~mL}$ of the dissolved test extract for 24 hours. After this period, the snails were washed, placed in dechlorinated water, and fed. The snails remained under observation for a further 24 hours, and the dead snails were recorded and removed. The extracts that exhibited molluscicidal activity at 
TABLE 1: Chemical composition and pharmacological activities of the plants used by the Pankararés, Bahia, northeast Brazil, as repellents or anthelmintics.

\begin{tabular}{|c|c|c|c|c|c|}
\hline Popular name & Family/Species & Part used & Biological activity & Isolated substances & References \\
\hline Pinhão branco ${ }^{\mathrm{B}}$ & $\begin{array}{c}\text { euphorbiaceae/ } \\
\text { Jatropha mollissima (Pohl) } \\
\text { Baill. }\end{array}$ & $\begin{array}{l}\text { Leaves, stem bark, } \\
\text { and roots }\end{array}$ & Antioxidant & $*$ & {$[20]$} \\
\hline Jurema preta ${ }^{\mathrm{B}}$ & $\begin{array}{c}\text { fabaceae/ } \\
\text { Mimosa tenuiflora } \\
\text { (Willd.) Poir. }\end{array}$ & $\begin{array}{l}\text { Leaves, stem bark, } \\
\text { and roots }\end{array}$ & $*$ & Kukulkanins A and B & {$[21]$} \\
\hline Velame & $\begin{array}{c}\text { euphorbiaceae/ } \\
\text { Croton moritibensis Baill. }\end{array}$ & $\begin{array}{l}\text { Leaves and aerial } \\
\text { parts }\end{array}$ & * & $\begin{array}{l}\text { 12-hydroxy-13-methyl-1,8,11,13- } \\
\text { podocarpatetraen-3-one, } \\
\text { 2-ethoxycarbonyltetrahydroharman } \\
\text { and hydroxy-2- } \\
\text { methyltetrahydroharman }\end{array}$ & {$[22]$} \\
\hline Vassourinha $^{\mathrm{B}}$ & $\begin{array}{l}\text { plantaginaceae/ } \\
\text { Scoparia dulcis L. }\end{array}$ & Aerial parts & $\begin{array}{c}\text { Antidiabetic, } \\
\text { antioxidant, cytotoxic, } \\
\text { antiulcer, } \\
\text { antileishmania, and } \\
\text { anti-hyperlipidemic }\end{array}$ & Scoparic acid D & {$[23-32]$} \\
\hline Pitó ${ }^{\mathrm{A}}$ & $\begin{array}{c}\text { sterculiaceae/ } \\
\text { Helicteres velutina } \mathrm{K} . \\
\text { Schum. }\end{array}$ & Aerial parts & $\begin{array}{l}\text { Cytotoxic against } \\
\text { various cancer } \\
\text { lineages }{ }^{* *}\end{array}$ & Cucurbitacins $\mathrm{D}$ and $\mathrm{J}^{* *}$ & {$[33]$} \\
\hline Mastruz $^{\mathrm{B}}$ & $\begin{array}{l}\text { chenopodiaceae/ } \\
\text { Chenopodium } \\
\text { ambrosioides L. }\end{array}$ & Aerial parts & $\begin{array}{l}\text { Inhibitor of the } \\
\text { mitochondrial electron } \\
\text { transport chain } \\
\text { (toxicity), antiparasitic, } \\
\text { antihyperperistalsis, } \\
\text { anti-inflammatory, } \\
\text { analgesic, } \\
\text { antischistosomiasis, } \\
\text { antituberculosis, } \\
\text { larvicidal, antitumor, } \\
\text { and antifungal }\end{array}$ & Caryophyllene oxide & [34-44]. \\
\hline Catingueira ${ }^{\mathrm{A}, \mathrm{B}}$ & $\begin{array}{c}\text { fabaceae/ } \\
\text { Poincianella pyramidalis } \\
\text { (Tul.) L.P. Queiroz }\end{array}$ & $\begin{array}{l}\text { Leaves, stem bark } \\
\text { and roots }\end{array}$ & $\begin{array}{l}\text { Antimicrobial, } \\
\text { antioxidant and } \\
\text { antifungal }\end{array}$ & $\begin{array}{l}4,4^{\prime} \text {-dihydroxy- } 2^{\prime} \text {-methoxy- } \\
\text { chalcone }\end{array}$ & {$[45-48]$.} \\
\hline Sambacaitá $^{B}$ & $\begin{array}{c}\text { lamiacae/ } \\
\text { Hyptis pectinata } \mathrm{L} .\end{array}$ & Aerial parts & $\begin{array}{c}\text { Antimicrobial, } \\
\text { antinociceptive, } \\
\text { anti-inflammatory, } \\
\text { hepatoprotective, } \\
\text { antibacterial, and } \\
\text { antifungal }\end{array}$ & Calamusenone-antimicrobial & [49-54]. \\
\hline
\end{tabular}

${ }^{*}$ No studies were found in the literature; ${ }^{* *}$ activity has been described for another species of the same genus; ${ }^{\mathrm{A}}$ larvicidal activity; ${ }^{\mathrm{B}}$ molluscicidal activity.

concentrations lower than $100 \mu \mathrm{g} / \mathrm{mL}$ in the duplicate bioassays were considered active and subjected to further tests. A total of 10 snails was used in these tests (maintaining the ratio of $25 \mathrm{~mL}$ of test solution per snail), and each concentration was tested in triplicate. In parallel, we carried out control tests using an aqueous solution of $0.1 \%$ DMSO with the molluscicide, niclosamide, at $3 \mu \mathrm{g} / \mathrm{mL}$. We used the program Probit, version 1.5 [55] to calculate the $\mathrm{LC}_{50}$.

The World Health Organization (WHO) has indicated that the crude extracts of plants presenting $\mathrm{LC}_{50}$ values of $<40 \mathrm{ppm}(0.04 \%$ and $0.4 \mu \mathrm{g} / \mathrm{mL})$ have potential as larvicidal and molluscicidal compounds [56].

2.5. Evaluation of the Larvicidal Activity. The larvicidal activity was tested on the larvae of the mosquito Aedes aegypti in the bioassay laboratory of the IQB/UFAL, based on methodology described by the WHO [57]. The crude extracts were diluted in aqueous solutions of $1 \%$ DMSO to $500 \mu \mathrm{g} / \mathrm{mL}$. Then, 10 larvae of $A$. aegypti in the fourth instar stage were prepared for immersion in the crude extract $(20 \mathrm{~mL})$. The larvae were counted 24 hours and 48 hours from the beginning of the experiment, and the tests were performed in quadruplicate. For the control, we used an aqueous solution of $1 \%$ DMSO containing $3 \mu \mathrm{g} / \mathrm{mL}$ of the synthetic larvicide, Temephos. The activity of the tested extracts was established based on the average percentage of mortality of the larvae after 48 hours ( $>75 \%$ [promising result], 50-75\% [partially promising], $25-50 \%$ [weakly promising], and $<25 \%$ [inactive]). 
TABLE 2: In vitro larvicidal activity of ethanolic extracts from Scoparia dulcis and Helicteres velutina. LC: Lethal concentration reported as $\mathrm{LC}_{10}, \mathrm{LC}_{50}$, and $\mathrm{LC}_{90}($ in $\mathrm{mg} / \mathrm{L})$.

\begin{tabular}{lccccc}
\hline Tested species & Popular name & Part used & LC $_{10}$ & LC $_{50}$ & LC $_{90}$ \\
\hline Scoparia dulcis & Vassourinha & Leaf & 43.820 & 83.426 & 158.829 \\
Helicteresvelutina & Pitó & Root & Stem & 63.029 & 171.683 \\
Helicteresvelutina & Pitó & & 60.406 & 138.896 & 319.372 \\
\hline
\end{tabular}<smiles>C=C(C)C1CCC2(C(=O)O)CCC3(C)C(CCC4C5(C)CCC(O)C(C)(C)C5CCC43C)C12</smiles>

(a)<smiles>C=C1CCC2C(C1)CC(OC(=O)c1ccccc1)C1C(CO)(C(=O)O)CCCC21C</smiles>

(b)<smiles>COC(=O)C1(CO)CCCC2(C)C1CC1CC(=O)C3CCC12C3OC(=O)c1ccccc1</smiles>

(c)

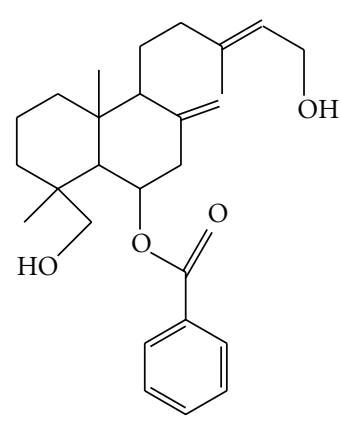

(d)<smiles>CC12CCC(CC1=O)C1(C)CCCC(O)(CO)C1C2OC(=O)c1ccccc1</smiles>

(e)<smiles>CC1(C(=O)O)CCCC2(C)C1C(OC(=O)C1CCCCC1)CC1CC3CC12CCC3(O)O</smiles>

(f)

Figure 1: Chemical structures of selected compounds isolated from S. dulcis: (a) betulinic acid, (b) scopadulcic acid A, (c) scopadulcic acid B, (d) scopadiol, (e) scopadulciol, and (f) scopadulin.

2.6. Data Analysis. The results are reported as the average of three repetitions $(n=3) \pm$ the standard deviation of the mean. The values found were subjected to ANOVA and Tukey's test $(P \leq 0.05)$. All of the analyses were performed using the Microcal Origin, version 8.0, and GraphPad Prism, version 5.0, programs.

\section{Results and Discussion}

The eight plant species examined belong to six families and eight genera, and a biological activity has previously been described in the literature for these species (Table 1). These species were cited by the Pankararé as insect repellents (5 species) and/or anthelmintics (4 species). The analyses of the extracts and the root, stem, and leaf fractions demonstrated that seven $(87.5 \%)$ of the eight tested species presented activity. Five species $(62.5 \%)$ were active against the mollusk, Biomphalaria glabrata, and two species $(25 \%)$ were active against larvae of the Aedes aegypti mosquito.

Two of the seven species with activity (Chenopodium ambrosioides L. and Hyptis pectinata Poit.) are cultivated in home gardens. The remaining five species (Helicteres velutina
K. Schum., Jatropha mollissima (Pohl) Baill., Poincianella pyramidalis (Tul.) L.P. Queiroz, Mimosa tenuiflora (Willd.) Poir., and Scoparia dulcis L.) are native or ruderal species.

The species with the strongest activity against the larvae of $A$. aegypti was $S$. dulcis, whose ethanolic leaf extract presented an $\mathrm{LC}_{50} 83.426 \mathrm{mg} / \mathrm{L}$. The next strongest activity was presented by Helicteres velutina $\mathrm{K}$. Schum., with an $\mathrm{LC}_{50}$ of $138.89 \mathrm{mg} / \mathrm{mL}$ and $171.68 \mathrm{mg} / \mathrm{L}$, respectively, for the extracts obtained from the stems $(215 \mathrm{~g})$ and roots (208 g) (Table 2).

Previous studies report that the extracts from the roots and stems of $S$. dulcis present a high activity against the bacterium Klebsiella pneumoniae and gram-negative bacteria [45]. Such results may be associated with the presence of steroids, saponins, polyphenols, and glutinol [58]. Flavonoids were also described as occurring in the aerial parts of S. dulcis [59], which suggests the presence of antioxidant activity. S. dulcis is a good source of betulinic acid (Figure 1), a compound with proven anticarcinogenic, antimelanoma, antiviral, and cytotoxic properties. Many biological activities that were found in S. dulcis have been attributed to various compounds, including scopadulcic acids A and B, scopadiol, scopadulciol, and scopadulin [60] (Figure 1). 
TABle 3: Molluscicidal activity against B. glabrata of plant extracts used by the Pankararé indigenous people (Bahia State, Brazil). LC: Lethal concentration reported as $\mathrm{LC}_{10}, \mathrm{LC}_{50}$, and $\mathrm{LC}_{90}$ (in $\mathrm{mg} / \mathrm{L}$ ).

\begin{tabular}{lccccc}
\hline Crude extract & Common name & Used part & LC $_{10}$ & LC $_{50}$ & LC $_{90}$ \\
\hline Jatropha mollissima & Pinhão-branco & Stem & 20.00 & 33.55 & 56.26 \\
Hyptis pectinata & Sambacaetá & Leaf & 8.48 & 25.34 & 75.66 \\
Poincianella pyramidalis & Catingueira & Leaf & 0.04 & 1.99 & 13.51 \\
Chenopodium ambrosoides & Mastruz & Leaf & 6.59 & 20.03 \\
Mimosa tenuiflora & Jurema preta & Stem & & 91.57 \\
\hline
\end{tabular}

No data were found in the literature that could be used in a comparative analysis of Helicteres velutina, a species whose roots and stems exhibited activity in the present study; such previously reported data were found only for Helicteres angustifolia L. [33]. The other species tested did not present activity against the larvae of $A$. aegypti using the applied method.

P. pyramidalis (Tul.) L.P. ( $\left.\mathrm{LC}_{50} 0.94 \mathrm{mg} / \mathrm{L}\right)$, C. ambrosoides ( $\left.\mathrm{LC}_{50} 13.51 \mathrm{mg} / \mathrm{L}\right)$, M. tenuiflora ( $\left.\mathrm{LC}_{50} 20.22 \mathrm{mg} / \mathrm{L}\right)$, H. pectinata ( $\mathrm{LC}_{50} 25.55 \mathrm{mg} / \mathrm{L}$ ), and J. molissima ( $\mathrm{LC}_{50}$ $33.55 \mathrm{mg} / \mathrm{L}$ ) demonstrated the strongest molluscicidal activities (Table 3). The extracts of C. moritibensis (the stems, roots, leaves, stem bark, and root bark) did not exhibit any significant activity, as based on the recommendations of the WHO [56]. These recommendations propose that only the aqueous and alcoholic extracts of plants that promote the death of $90 \%$ of the animals when tested at concentrations equal to or lower than $20 \mathrm{mg} / \mathrm{L}$ (over a 24-hour exposure) should be tested in the field and deserve attention in studies on the purification and isolation of the most active compounds.

The ethanolic extract of $P$. pyramidalis has been used successfully against resistant strains of Escherichia coli (strain ATCC25922) and Staphylococcus aureus (ATCC25923) [48]. A phytochemical study of this species revealed the presence of phenolic compounds, such as glucosyl-phenylpropanoid acid, 4-Obd-glucopyranosyloxi-Z-7-hydroxycinnamic acid and 4-O-b-glucopyranosyloxi-Z-8-hydroxycinnamic acid, and flavonoids agathisflavone, apigenin, and kaempferol [53] (Figure 2).

The excellent efficacy of this species is important, and the crude extract deserves further studies with regard to the purification and isolation of the most active compounds. Importantly, P. pyramidalis occurs frequently and this species grows densely in semiarid dry forest in northeastern Brazil, locally known as caatinga [61], presenting the strong potential for large-scale exploitation without incurring a major risk to its population and the possibility of generating income for local communities and creating major public health benefits.

Mastruz (C. ambrosoides), which was the second most efficacious species, provides an essential oil containing the active ingredient monoterpene ascaridol [62]. The essential oil of this species has been used as an anthelmintic in humans but, due to its high toxicity, it has been replaced with safer drugs [63].
In a review on the phytochemistry of jurema-preta, Souza et al. [64] report the presence of several metabolites, such as alkaloids, chalcones, steroids, terpenoids, and phenoxychromones. Choi et al. [65] has suggested that many biological plant activities are due to the presence of total phenols, such as flavonoids and tannins.

Sambacaitá (H. pectinata), which is also bioactive, has proven anti-inflammatory, hepatoprotective, antibacterial, antifungal, and antinociceptive action [49-54].

The bark extract from J. mollissima was more toxic to the A. aegypti larvae than the leaf or root extracts. These results are similar to those found by Heal et al. [66].

The diterpenoids, jatrophone, and jatropholones A and B (Figure 3), are classified as cytotoxic substances, and the isolation of tumor growth inhibitors from this plant has been cited by Goulart et al. [67] and Kupchan et al. [68, 69]. These substances have been the subject of several scientific studies and have been reported to inhibit the effects of insulin [70].

Although previous researchers have studied the bioactive substances of seven of the eight species examined here, no reference was found concerning its molluscicidal or larvicidal potential.

Although there is a need for further investigation to isolate and identify the constituents of the crude plant extracts studied, the results of this study provide evidence that some of the plants tested contain natural insecticides and have the potential for larvicidal activity and may provide substitutes for synthetic products in the future. Developments in this direction may lead to important positive impacts on public health programs, particularly with regard to socially excluded populations.

\section{Conclusion}

During the molluscicidal tests, we verified that the leaf extracts of Poincianella pyramidalis and Chenopodium ambrosoides were very effective and had a high level of activity. However, other extracts were more promising for larvicidal activity; of particular note were the leaf extracts from Scoparia dulcis and the stem and root extracts of Helicteres velutina. Based on these results, the plants of the studied region have proven to be a rich source of substances with larvicidal activity (based on Aedes aegypti larvae in the fourth instar) and molluscicidal activity (based on the snail Biomphalaria glabrata). Further attention is warranted for the purification and isolation of the most active compounds 


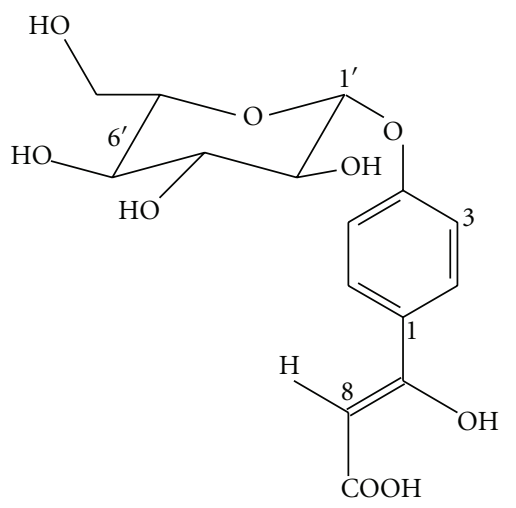

(a)<smiles>O=c1c(O)c(-c2ccc(O)cc2)oc2cc(O)cc(O)c12</smiles>

(d)<smiles>O=C(O)/C(O)=C/c1ccc(OC2OC3C(O)C(O)C(O2)C(O)C3O)cc1</smiles>

(b)<smiles></smiles>

(c)<smiles>O=c1cc(-c2ccc(O)cc2)oc2cc(O)cc(O)c12</smiles>

(e)

FIGURE 2: Chemical structures of some compounds isolated from P. pyramidalis: (a) apigenin, kaempferol and (b) agathisflavone.

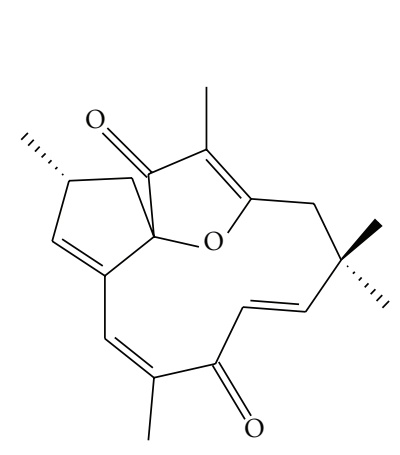

(a)

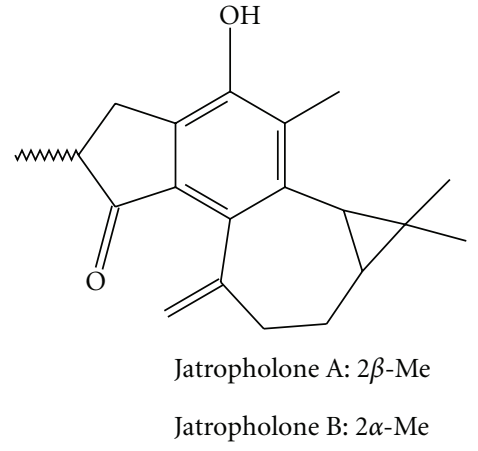

(b)<smiles>COc1cc(/C=C/C(=O)OCc2ccccc2)ccc1O</smiles>

(c)

FIGURE 3: Chemical structures of some compounds isolated from plants of the genus Jatropha: (a) jatrophone, (b) jatropholone A and B, (c) ferulates.

from these extracts, and field tests are needed. From the information presented here, the need for an interdisciplinary research program in the northeastern semiarid region is evident, especially in the village of the Pankararé people. Such a program would be aimed at developing the sustainable use of natural resources and promoting community development.

\section{Acknowledgments}

The authors wish to express their gratitude to the indigenous community of the Pankararé (Cacique Afonso and Patrícia) and to Professor Charles Estevão from the Laboratory of Biochemistry and Chemistry of Natural Products (LBPN) of UFS, FUNAI, FUNASA, UNEB, CNPq, and CAPES. 


\section{References}

[1] Programa das Nações Unidas para o Desenvolvimento, "A verdadeira riqueza das nações: vias para o desenvolvimento humano," 2010, http://www.pnud.org.br/rdh .

[2] P. Hotez, "A new voice for the poor," PLoS Neglected Tropical Diseases, vol. 1, no. 1, article e77, 2007.

[3] A. Marston and K. Hostettmann, "Plant molluscicides," Phytochemistry, vol. 24, no. 4, pp. 639-652, 1985.

[4] A. R. Bilia, A. Braca, J. Mendez, and I. Morelli, "Molluscicidal and piscicidal activities of Venezuelan chrysobalanaceae plants," Life Sciences, vol. 66, no. 4, pp. 53-59, 2000.

[5] V. S. Delgado, D. P. Suarez, I. M. Cesari, and R. N. Incani, "Experimental chemotherapy of Schistosoma mansoni with praziquantel and oxamniquine: differential effect of single or combined formulations of drugs on various strains and on both sexes of the parasite," Parasitology Research, vol. 78, no. 8, pp. 648-654, 1992.

[6] U. P. Albuquerque and N. Hanazaki, "As pesquisas etnodirigidas na descoberta de novos fármacos de interesse médico e farmacêutico: fragilidades e pespectivas," Revista Brasileira de Farmacognosia, vol. 16, 2006.

[7] A. F. dos Santos, M. R. F. De Lima, M. C. De Omena et al., "A study of the larvicidal and molluscicidal activities of some medicinal plants from northeast Brazil," Journal of Ethnopharmacology, vol. 97, no. 2, pp. 199-206, 2005.

[8] L. T. G. Ruiz, E. G. Magalhães, A. F. Magalhães et al., "Avaliação da atividade tóxica em Artemia salina e Biomphalaria glabrata de extratos de quatro espécies do gênero Eleocharis (Cyperaceae)," Revista Brasileira de Farmacognosia, vol. 15, no. 2, 2005.

[9] R. R. N. Alves, J. A. A. Barbosa, S. L. D. X. Santos, W. M. S. Souto, and R. R. D. Barboza, "Animal-based remedies as complementary medicines in the semi-arid region of northeastern Brazil," Evidence-Based Complementary and Alternative Medicine, vol. 2011, Article ID 179876, 15 pages, 2011.

[10] F.M Garelli, M. O. Espinosa, D. Weinberg, M. A. Trinelli, and R. E. Gürtler, "Water use practices limit the effectiveness of a temephos-based Aedes aegypti larval control program in northern Argentina," PLoS Neglected Tropical Diseases, vol. 3, no. 5, p. 991, 2011.

[11] R. Bhopal, "Seven mistakes and potential solutions in epidemiology, including a call for a World Council of Epidemiology and Causality," Emerging Themes in Epidemiology, vol. 6, article 6, 2009.

[12] F. P. S. F. Bandeira, Etnobiologia Pankararé. Salvador. Monografia De Bacharelado em Ciências Biológicas, Instituto de Biologia da UFBA, 1993.

[13] M. A. D. S. Colaço, Etnobotânica dos índios Pankararé, no Raso da Catarina-Bahia: Uso e Importância Cultural de Plantas da Caatinga, M.S. thesis, Feira de Santana, Bahia, Brazil, 2006.

[14] Ministério das Minas e Energia Secretaria Geral, "Projeto RADAMBRASIL: folha SC.24/25 Aracaju/Recife; geologia, geomorfologia, pedologia, vegetação e usopotencial da terra," Rio de Janeiro, Brasil: 856p., il., 7 mapas, (Levantamento de Recursos Naturais, 30), 1983.

[15] M. S. Maia, Os Pankararé do Brejo do Burgo Capesinato e Etnicidade. Monografia do Bacharelado e Antropologia, Universidade Federal da Bahia, 1992.

[16] F. P. F. Bandeira, Diagnóstico Etnoambiental da Terra indígena Pankararé, UEFS, 2003.
[17] E. A. Santos, Análise fitoquimica e ensaios biológicos de plantas da caatinga utilizada pelos indios pankarare da estação ecológica do raso da catarina, Ph.D. thesis, Programa de Pós Graduação em Quimica e Biotecnologia, Universidade Federal de Alagoas, 2011.

[18] U. P. Albuquerque and R. F. P. Lucena, Métodos Etécnicas na Pesquisa Etnobotânica, Livro Rápido/NUPPEA, Recife, Brasil, 2004.

[19] A. F. dos Santos and A. E. G. Sant'ana, "Molluscicidal activity of the diterpenoids jatrophone and jatropholones A and B isolated from Jatropha elliptica (Pohl) Muell. Arg," Phytotherapy Research, vol. 13, no. 8, pp. 660-664, 1999.

[20] J. G. De Melo, T. A. De Sousa Araújo, V. T. N. De Almeida Castro et al., "Antiproliferative activity, antioxidant capacity and tannin content in plants of semi-arid northeastern Brazil," Molecules, vol. 15, no. 12, pp. 8534-8542, 2010.

[21] X. A. Dominguez, S. G. Garcia, H. J. Williams, C. Ortiz, A. I. Scott, and J. H. Reibenspies, "Kukulkanins A and B, new chalcones from Mimosa tenuefolia," Journal of Natural Products, vol. 52, no. 4, pp. 864-867, 1989.

[22] V. T. De Araújo-Júnior, M. S. Da Silva, E. V. Leitao Da-Cunha et al., "Alkaloids and diterpenes from Croton moritibensis," Pharmaceutical Biology, vol. 42, no. 1, pp. 62-67, 2004.

[23] M. A. Adaikpoh, N. E. J. Orhue, and I. Igbe, "The protective role of Scoparia dulcis on tissue antioxidant defense system of rats exposed to cadmium," African Journal of Biotechnology, vol. 6, no. 10, pp. 1192-1196, 2007.

[24] M. Ahsan, S. K. N. Islam, A. I. Gray, and W. H. Stimson, "Cytotoxic diterpenes from Scoparia dulcis," Journal of Natural Products, vol. 66, no. 7, pp. 958-961, 2003.

[25] M. Babincová, K. Schronerová, and P. Sourivong, "Antiulcer activity of water extract of Scoparia dulcis," Fitoterapia, vol. 79, no. 7-8, pp. 587-588, 2008.

[26] J. E. Beh, J. Latip, M. P. Abdullah, A. Ismail, and M. Hamid, "Scoparia dulcis (SDF7) endowed with glucose uptake properties on L6 myotubes compared insulin," Journal of Ethnopharmacology, vol. 129, no. 1, pp. 23-33, 2010.

[27] M. S. Gachet, J. S. Lecaro, M. Kaiser et al., "Assessment of antiprotozoal activity of plants traditionally used in Ecuador in the treatment of leishmaniasis," Journal of Ethnopharmacology, vol. 128, no. 1, pp. 184-197, 2010.

[28] M. Latha, L. Pari, S. Sitasawad, and R. Bhonde, "Scoparia dulcis, a traditional antidiabetic plant, protects against streptozotocin induced oxidative stress and apoptosis in vitro and in vivo," Journal of Biochemical and Molecular Toxicology, vol. 18, no. 5, pp. 261-272, 2004.

[29] M. Latha, L. Pari, K. M. Ramkumar et al., "Antidiabetic effects of scoparic acid D isolated from scoparia dulcis in rats with streptozotocin-induced diabetes," Natural Product Research, vol. 23, no. 16, pp. 1528-1540, 2009.

[30] S. Mesía-Vela, M. Bielavsky, L. M. B. Torres et al., "In vivo inhibition of gastric acid secretion by the aqueous extract of Scoparia dulcis L. in rodents," Journal of Ethnopharmacology, vol. 111, no. 2, pp. 403-408, 2007.

[31] L. Pari and M. Latha, "Protective role of Scoparia dulcis plant extract on brain antioxidant status and lipidperoxidation in STZ diabetic male Wistar rats," BMC Complementary and Alternative Medicine, vol. 4, article 16, 2004.

[32] L. Pari and M. Latha, "Antihyperlipidemic effect of Scoparia dulcis (Sweet Broomweed) in streptozotocin diabetic rats," Journal of Medicinal Food, vol. 9, no. 1, pp. 102-107, 2006. 
[33] Z. T. Chen, S. W. Lee, and C. M. Chen, "Cucurbitacin B 2-sulfate and cucurbitacin glucosides from the root bark of Helicteres angustifolia," Chemical and Pharmaceutical Bulletin, vol. 54, no. 11, pp. 1605-1607, 2006.

[34] J. L. Bezerra, Avaliação da atividade leishmanicida de espécies vegetais, M.S. thesis, Universidade Federal do Maranhão, 2006.

[35] F. Calzada, R. Arista, and H. Pérez, "Effect of plants used in Mexico to treat gastrointestinal disorders on charcoal-gum acacia-induced hyperperistalsis in rats," Journal of Ethnopharmacology, vol. 128, no. 1, pp. 49-51, 2010.

[36] G. F. Ibironke and K. I. Ajiboye, "Studies on the anti-inflammatory and analgesic properties of Chenopodium ambrosioides leaf extract in rats," International Journal of Pharmacology, vol. 3, no. 1, pp. 111-115, 2007.

[37] E. G. Kamel, M. A. El-Emam, S. S. M. Mahmoud, F. M. Fouda, and F. E. Bayaumy, "Attenuation of Schistosoma mansoni cercarial infectivity to albino mice by methanol extract of some plant species," Pesticide Biochemistry and Physiology, vol. 98, no. 3, pp. 342-348, 2010.

[38] F. Kiuchi, Y. Itano, N. Uchiyama et al., "Monoterpene hydroperoxides with trypanocidal activity from Chenopodium ambrosioides," Journal of Natural Products, vol. 65, no. 4, pp. 509512, 2002.

[39] N. Lall and J. J. M. Meyer, "In vitro inhibition of drug-resistant and drug-sensitive strains of Mycobacterium tuberculosis by ethnobotanically selected South African plants," Journal of Ethnopharmacology, vol. 66, no. 3, pp. 347-354, 1999.

[40] F. Massebo, M. Tadesse, T. Bekele, M. Balkew, and T. GebreMichael, "Evaluation on larvicidal effects of essential oils of some local plants against Anopheles arabiensis Patton and Aedes aegypti Linnaeus (Diptera, Culicidae) in Ethiopia," African Journal of Biotechnology, vol. 8, no. 17, pp. 4183-4188, 2009.

[41] L. Monzote, W. Stamberg, K. Staniek, and L. Gille, "Toxic effects of carvacrol, caryophyllene oxide, and ascaridole from essential oil of Chenopodium ambrosioides on mitochondria," Toxicology and Applied Pharmacology, vol. 240, no. 3, pp. 337$347,2009$.

[42] F. R. F. Nascimento, G. V. B. Cruz, P. V. S. Pereira et al., "Ascitic and solid Ehrlich tumor inhibition by Chenopodium ambrosioides L. treatment," Life Sciences, vol. 78, no. 22, pp. 26502653, 2006.

[43] F. J. Patrício, G. C. Costa, P. V. S. Pereira et al., "Efficacy of the intralesional treatment with Chenopodium ambrosioides in the murine infection by Leishmania amazonensis," Journal of Ethnopharmacology, vol. 115, no. 2, pp. 313-319, 2008.

[44] C. S. Prasad, R. Shukla, A. Kumar, and N. K. Dubey, "In vitro and in vivo antifungal activity of essential oils of Cymbopogon martini and Chenopodium ambrosioides and their synergism against dermatophytes," Mycoses, vol. 53, no. 2, pp. 123-129, 2009.

[45] W. S. Alviano, D. S. Alviano, C. G. Diniz et al., "In vitro antioxidant potential of medicinal plant extracts and their activities against oral bacteria based on Brazilian folk medicine," Archives of Oral Biology, vol. 53, no. 6, pp. 545-552, 2008.

[46] M. V. Bahia, J. B. dos Santos, J. P. David, and J. M. David, "Biflavonoids and other phenolics from Caesalpinia pyramidalis (Fabaceae)," Journal of the Brazilian Chemical Society, vol. 16, no. 6 B, pp. 1402-1405, 2005.

[47] M. C. S. Cruz, P. O. Santos, A. M. Barbosa et al., "Antifungal activity of Brazilian medicinal plants involved in popular treatment of mycoses," Journal of Ethnopharmacology, vol. 111, no. 2, pp. 409-412, 2007.
[48] M. R. F. De Lima, J. de Souza Luna, A. F. dos Santos et al., "Anti-bacterial activity of some Brazilian medicinal plants," Journal of Ethnopharmacology, vol. 105, no. 1-2, pp. 137-147, 2006.

[49] M. F. Arrigoni-Blank, A. R. Antoniolli, L. C. Caetano, D. A. Campos, A. F. Blank, and P. B. Alves, "Antinociceptive activity of the volatile oils of Hyptis pectinata L. Poit. (Lamiaceae) genotypes," Phytomedicine, vol. 15, no. 5, pp. 334-339, 2008.

[50] M. D. Bispo, R. H. V. Mourão, E. M. Franzotti et al., "Antinociceptive and antiedematogenic effects of the aqueous extract of Hyptis pectinata leaves in experimental animals," Journal of Ethnopharmacology, vol. 76, no. 1, pp. 81-86, 2001.

[51] A. C. C. D. Lisboa, I. C. M. Mello, R. S. Nunes et al., "Antinociceptive effect of Hyptis pectinata leaves extracts," Fitoterapia, vol. 77, no. 6, pp. 439-442, 2006.

[52] G. B. Melo, R. L. Silva, V. A. Melo et al., "Enhancement of liver regeneration by the association of Hyptis pectinata with laser therapy," Digestive Diseases and Sciences, vol. 50, no. 5, pp. 949-954, 2005.

[53] P. F. C. Nascimento, W. S. Alviano, A. L. C. Nascimento et al., "Hyptis pectinata essential oil: chemical composition and antiStreptococcus mutans activity," Oral Diseases, vol. 14, no. 6, pp. 485-489, 2008.

[54] P. O. Santos, M. D. J. C. Costa, J. A. B. Alves et al., "Chemical composition and antimicrobial activity of the essential oil of Hyptis pectinata (L.) Poit," Quimica Nova, vol. 31, no. 7, pp. 1648-1652, 2008.

[55] EPA, 2004, http://www.epa.gov/nerleerd/stat2.htm\#probit .

[56] World Health Organization (WHO), Tropical Disease Research, World Health Organization, Geneva, Switzerland, 1993.

[57] World Health Organization (WHO), "Instruction for determining the susceptibility or resistance of mosquito larvae to insecticides," WHO/VBC/75.583, 1975.

[58] S. M. De Farias Freire, J. A. Da Silva Emim, A. J. Lapa, C. Souccar, and L. M. Brandao Torres, "Analgesic and antiinflammatory properties of Scoparia dulcis L. extracts and glutinol in rodents," Phytotherapy Research, vol. 7, no. 6, pp. 408-414, 1993.

[59] L. M. B. O. Torres, J. W. B. Sobrinho, K. R. S. Marques et al., "Compostos polares de scoparia dulcis (Scrophulariaceae)," in Proceedings of the 17th Reunião Anual da Sociedade Brasileira de Química, 7th Simpósio Nacional de Química Inorgânica, Caxambu, Brasil, 1994.

[60] Raintree Brasil, 2010, http://www.raintree.com.br/produtos/ ntense2.htm\#Scene_1.

[61] E. V. S. B. Sampaio, "Fitossociologia," in Pesquisa Botânica Nordestina: Progresso e Perspectivas, E. V. S. B. Sampaio, S. J. Mayo, and M. R. V. Barbosa, Eds., pp. 203-230, Sociedade Botânica do Brasil, Seção Regional de Pernambuco, 1996.

[62] H. Lorenzi and F. J. A. Matos, Plantas Medicinais do Brasil: Nativas e Exóticas Cultivadas, Instituto Plantarum, Nova Odessa, São Paulo, Brazil, 2002.

[63] H. Paget, "The determination of ascaridole in chenopodium oil," The Analyst, vol. 51, no. 601, pp. 170-176, 1926.

[64] R. S. O. de Souza, U. P. De Albuquerque, J. M. Monteiro, and E. L. C. De Amorim, "Jurema-Preta (Mimosa tenuiflora [Willd.] Poir.): a review of its traditional use, phytochemistry and pharmacology," Brazilian Archives of Biology and Technology, vol. 51, no. 5, pp. 937-947, 2008.

[65] Y. M. Choi, D. O. Noh, S. Y. Cho, H. J. Suh, K. M. Kim, and J. M. Kim, "Antioxidant and antimicrobial activities of propolis from several regions of Korea," LWT_Food Science and Technology, vol. 39, no. 7, pp. 756-761, 2006. 
[66] R. E. Heal, E. F. Rogers, R. T. Wallace, and O. Starnes, "A survey of plants for insecticidal activity," Lloydia, vol. 13, no. 2, pp. 89-162, 1950.

[67] M. O. F. Goulart, A. E. G. Sant'ana, R. A. Lima, S. H. Cavalcante, M. G. Carvalho, and F. R. Braz, "Fitoconstituintes químicos isolados de jatropha elliptica. Atribuição dos deslocamentos químicos dos Átomos de carbono e hidrogênio dos diterpenos jatrofolonas A e B," Química Nova, vol. 16, 1993.

[68] S. M. Kupchan, C. W. Sigel, M. J. Matz, C. J. Gilmore, and R. F. Bryan, "Structure and stereochemistry of jatrophone, a novel macrocyclic diterpenoid tumor inhibitor," Journal of American Chemical Society, vol. 98, no. 8, pp. 2295-2300, 1976.

[69] S. M. Kupchan, C. W. Sigel, M. J. Matz, J. A. S. Renauld, R. C. Haltiwanger, and R. F. Bryan, "Jatrophone, a novel macrocyclic diterpenoid tumor inhibitor from Jatropha gossypiifolia," Journal of the American Chemical Society, vol. 92, no. 14, pp. 4476-4477, 1970.

[70] F. V. Menezes, E. M. Carneiro, E. Delattre, and A. C. Boschero, "Inhibition of insulin release by Jatrophone," Brazilian Journal of Medical and Biological Research, vol. 25, no. 3, pp. 305-307, 1992. 


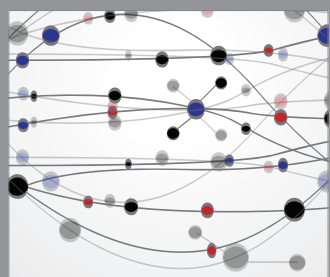

The Scientific World Journal
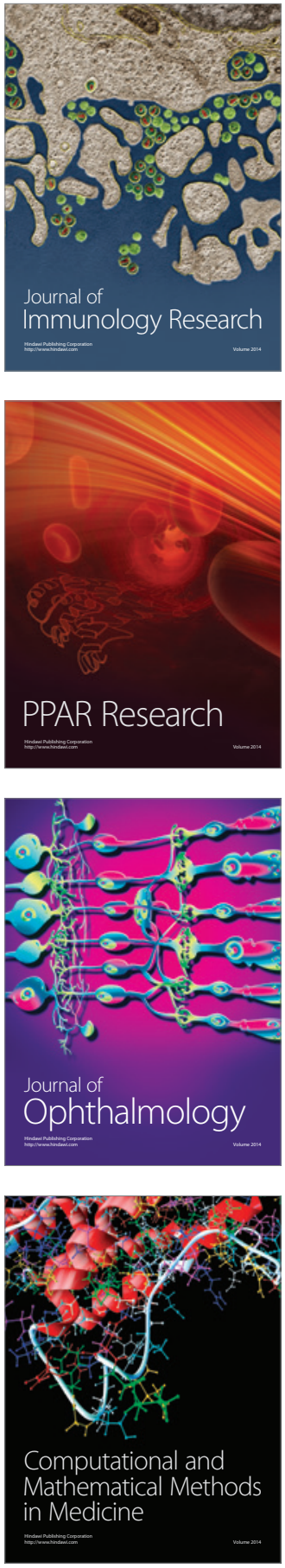

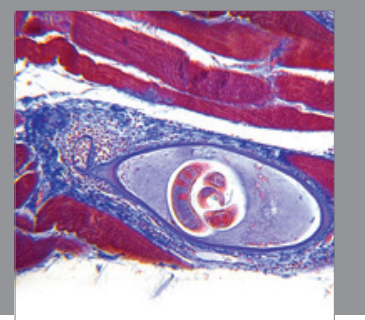

Gastroenterology

Research and Practice
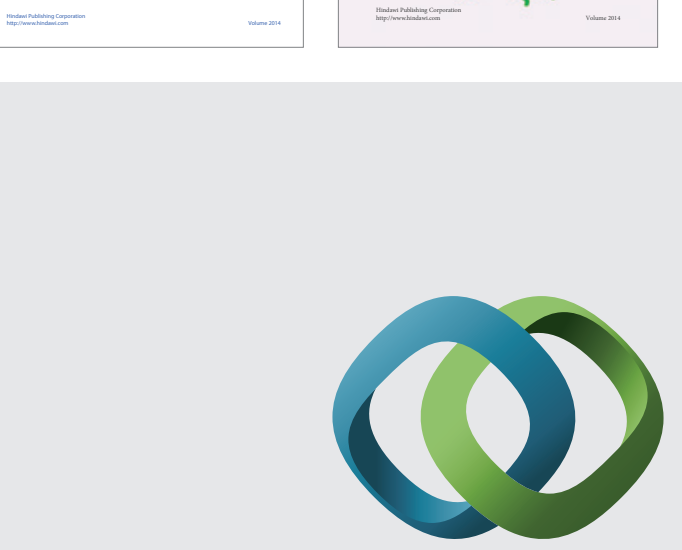

\section{Hindawi}

Submit your manuscripts at

http://www.hindawi.com
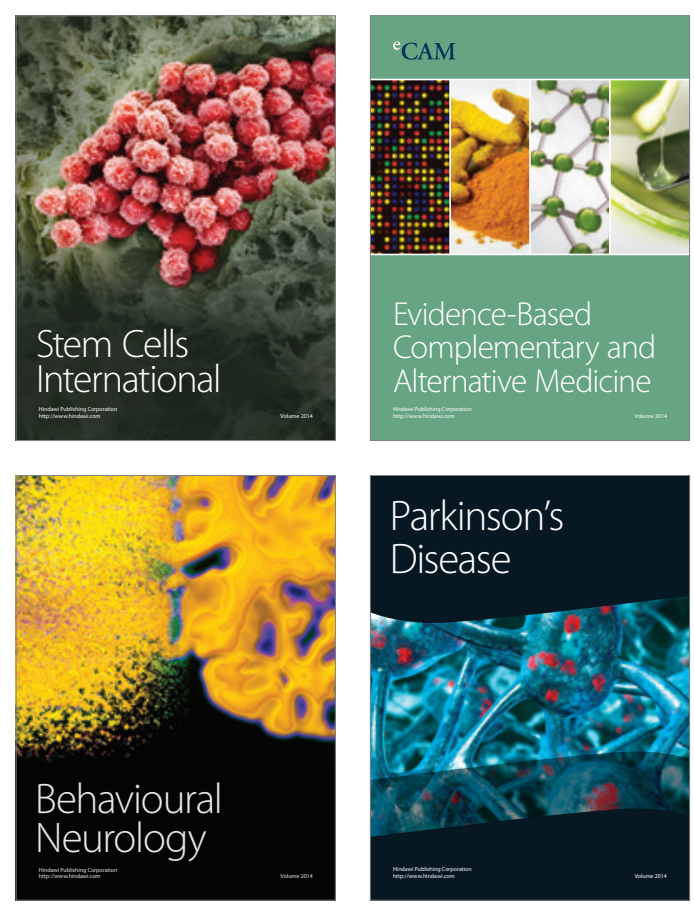

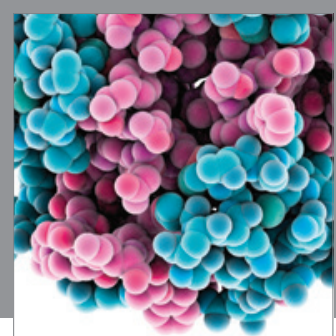

Journal of
Diabetes Research

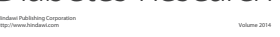

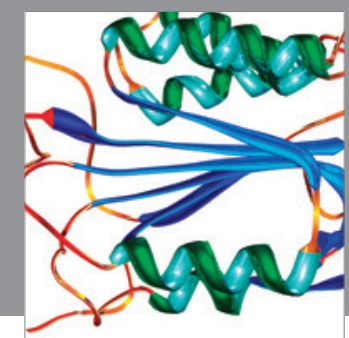

Disease Markers
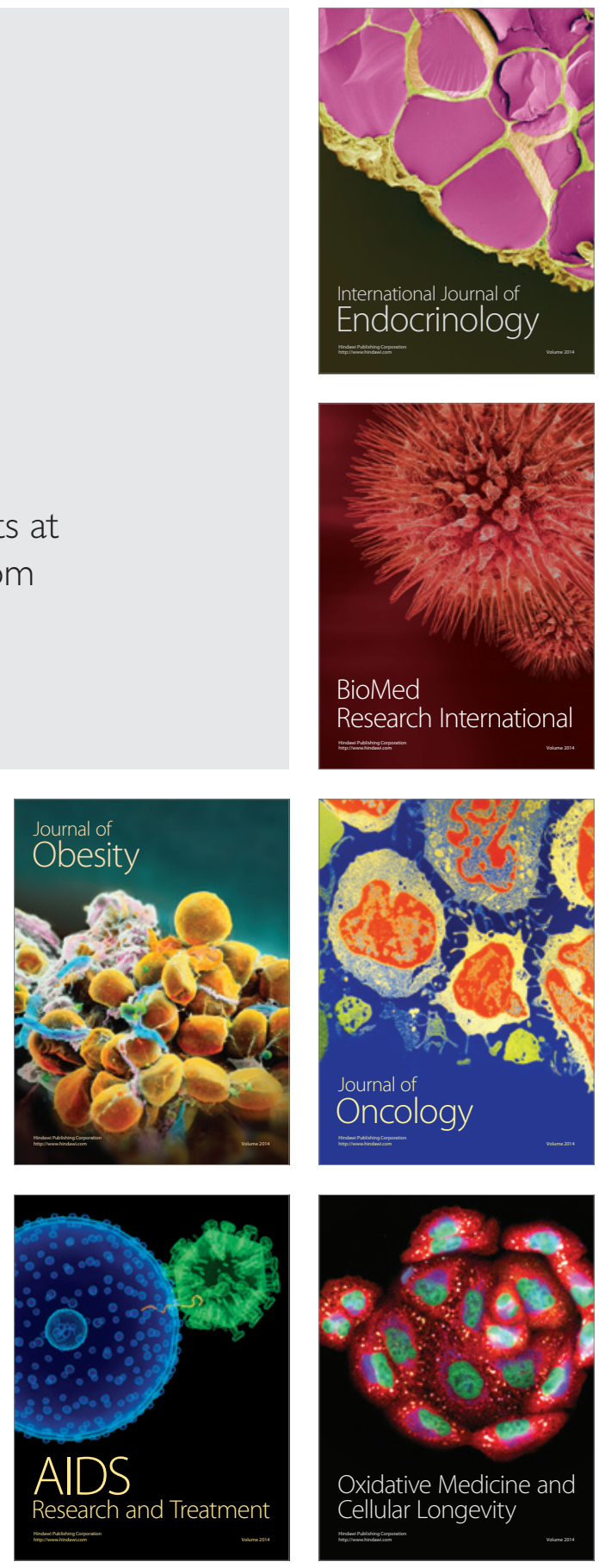